\title{
SURVIVAL ON MAINTENANCE DIALYSIS IN PATIENTS WITH CHRONIC RENAL FAILURE ASSOCIATED WITH PARAPLEGIA AND QUADRIPLEGIA
}

By M. K. Mirahmadi, M.D., F.A.C.P., N. D. Vaziri, M.D., F.A.C.P., M. Ghobadi, B. NiKaKhTAR, M.D. and S. Gordon, M.D.

Hemodialysis Unit, VA Medical Center, Long Beach, CA. Division of Nephrology, University of California, Irvine, CA. and Spinal Cord Injury Service, VA Medical Center, Long Beach, California

\begin{abstract}
Forty men with end-stage renal failure associated with spinal cord injury were treated with maintenance hemodialysis. There were 28 paraplegic and 12 quadriplegic patients. Survival on dialysis was significantly shorter in quadriplegics $(5.5 \pm 5.0$ months) than paraplegics $(22.9 \pm 27.0$ months). The cumulative I- and 2-year survival in paraplegics were 60 per cent and 52 per cent respectively. The respective values for quadriplegics were 34 per cent and I7 per cent. Various infections proved to be the immediate cause of death in the majority of our patients.
\end{abstract}

Key words: Spinal cord injury; Chronic renal failure; Hemodialysis; Survival.

\section{Introduction}

RENAL disease is a common complication of spinal cord injury (SCI) and, according to Tribe and Silver (1969), the cause of death in 75 per cent of the patients with this condition. These authors have suggested that in the absence of renal complications paraplegic patients may have a normal life expectancy. The life expectancy of the SCI patients with renal failure can therefore improve considerably by dialytic therapy. Acute renal failure has been successfully treated with peritoneal dialysis and hemodialysis in SCI patients with reversible renal failure (Mitchell et al., I964). Very little, however, has been published on maintenance hemodialysis in SCI patients with end-stage renal disease (ESRD). In 1977 we (Mirahmadi et al., 1977) reported our 3-year experience with maintenance hemodialysis in a group of SCI patients with ESRD. The present study is intended to report the survival data on 40 such patients treated at the SCI hemodialysis unit at Long Beach VA Medical Centre since 1972.

\section{Patients and Methods}

A total of 58 SCI patients with renal failure received hemodialysis treatment in our unit during the last 9 years, approximately seven new patients per year. Forty-three patients had paraplegia and Is had quadriplegia. Twelve patients were deemed to have acute renal failure and were excluded from this study. An

This project was supported partly by the funds generously provided by the late E. G. Reinis and VA Paraplegic Foundation.

All correspondence should be addressed to: Mike K. Mirahmadi, M.D., F.A.C.P., Chief, Hemodialysis Unit (I I INI), 590I East 7th Street, Long Beach, CA 90822, U.S.A. 
additional six patients were temporarily treated in our unit and transferred to other institutions and were lost to follow-up. Data on the remaining 40 male patients are included in the present study. They were all males, aged 26 to 64 years. Of the 40 patients nine patients are currently alive and $3 \mathrm{I}$ have died. Twenty-eight of these were paraplegic and 12 were quadriplegic. One of our paraplegic patients who survived for Io years was treated with hemodialysis elsewhere for 3 years. He was transferred to our unit in 1972 and died in 1979.

Blood access was established when the creatinine clearance fell below to to I $5 \mathrm{ml}$ per minute or BUN and creatinine exceeded 80 and $8 \mathrm{mg} / \mathrm{dl}$ respectively. Attempts were made to create Cimino arteriovenous fistulae whenever possible. In most instances, however, this was not successful and polytetrafluoro-ethylene (PTFE) grafts or external A-V shunts had to be placed. Dialysis was carried out 4-6 hours a day and two to three times a week, using parallel flow or hollow fibre dialysers. Drake Willock proportioning units were used with single pass dialysate flow of $500 \mathrm{ml} / \mathrm{min}$. Blood flow was maintained at $150-200 \mathrm{ml} / \mathrm{min}$. Ultrafiltration was measured by weight loss using the Brookline Automatic bed scale. Dialysate calcium concentration was maintained at $7 \mathrm{mg} / \mathrm{dl}$.

All beds were equipped with overhead swing bars to facilitate the patients' movements and 'egg crate' mattresses were used to prevent bed sores.

The diet contained 80 grams or more protein per day to maintain the serum albumin at $3.5 \mathrm{~g} / \mathrm{dl}$ or greater. Dietary sodium was restricted to $2 \mathrm{~g}$ /day when indicated (i.e. hypertension, oedema or interdialytic weight gain exceeding $\mathrm{I} \cdot 5$ $\mathrm{kg}$ /day). Dietary potassium was restricted to two to three grams per day to maintain predialysis serum level below $5.5 \mathrm{mEq} / \mathrm{l}$. Caloric intake was not restricted. All patients received folic acid ( $1 \mathrm{mg} /$ day) and multivitamins.

Aluminium carbonate was used to maintain predialysis phosphate level between 4 and $6 \mathrm{mg} / \mathrm{dl}$. Sustained hypertension was treated with salt and water restriction, ultrafiltration and antihypertensive medications. Severe episodic hypertension associated with autonomic dysreflexia was treated by elimination of the cause, i.e. proper management of urinary retention and prevention and management of severe constipation and fecal impaction. Bowel care was dealt with on nondialysis days when necessary. Blood transfusion was reserved for symptomatic anaemia, e.g., severe dyspnoea, weakness, angina, etc. and for hematocrit below I7 per cent (arbitrary level). Urine culture was obtained regularly and patients with symptomatic urinary tract infection were treated. Prophylactic antibiotic therapy was used only for blood access surgery and consisted of vancomycin $\mathrm{I} \cdot 0 \mathrm{~g}$ in $200 \mathrm{ml}$ normal saline administered intravenously once a week for 2 weeks. Bed sores were managed by the staff physicians. Student's $t$-test was used to determine the degree of significance in the two groups. The life table method described by Cutler et al. (1958) was used to determine the survival data, and methodology reported by Siemsen et al. (1973) was used to compare the mortality figures.

\section{Results}

Of the 40 patients studied 28 were paraplegic and 12 were quadriplegic. Mean age and duration between spinal cord injury and onset of end-stage renal failure necessitating dialysis were not significantly different in the two groups. Survival on dialysis, however, was significantly shorter in quadriplegics $(5.5 \pm 5.0$ months $)$ than paraplegics $(22 \cdot 9 \pm 27 \cdot 0$ months). Application of the life table analysis method reported by Cutler et al. (1958) indicated that I year cumulative survival was 60 per cent in paraplegics and 34 per cent in quadriplegics (Fig. I) and 2-year survival was 


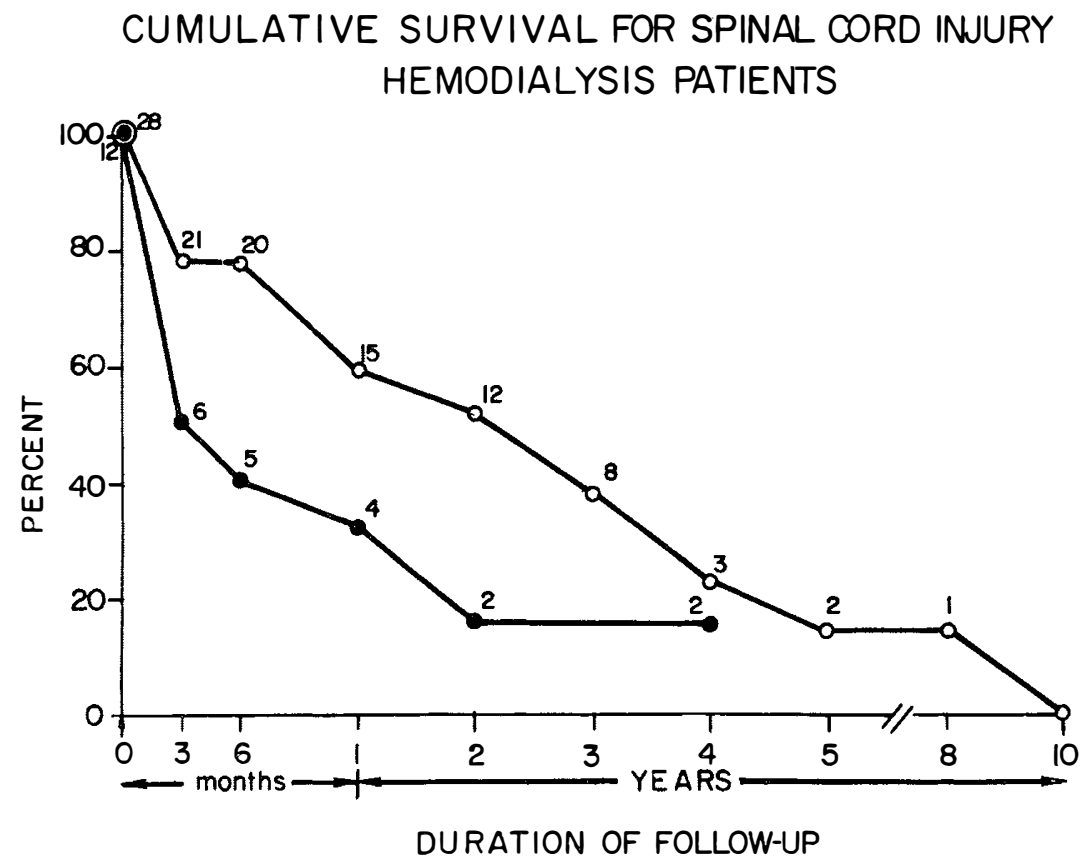

FIG. I

Cumulative survival data for SCI dialysis patients.

Open circles represent paraplegic patients.

Solid circles represent quadriplegic patients.

52 per cent for the former and 17 per cent for the latter. Using the statistical method proposed by Siemsen et al. (1973) revealed a mortality rate of 30 deaths per 1000 months therapy in paraplegic patients and 75 deaths per 1000 months therapy in quadriplegic subjects $(p<0.001)$. The aetiology of renal failure was primarily chronic pyelonephritis with or without renal amyloidosis. Due to the referral nature of our dialysis unit the total number of SCI patients, and therefore the incidence of ESRD among them, could not be determined. Various infectious complications constituted the main cause of death in our patients (Table I).

\section{TABLE I}

Causes of death in spinal cord injury patients with ESRD maintained on hemodialysis*

\begin{tabular}{lcc}
\hline & Paraplegics $\%$ & Quadriplegics $\%$ \\
\hline Septic shock & 7 I & 40 \\
Peritonitis & $2 \mathrm{I}$ & 60 \\
Cardiovascular & 28 & 20 \\
Bowel obstruction & 7 & - \\
Carcinomatosis & - & 20 \\
\hline
\end{tabular}

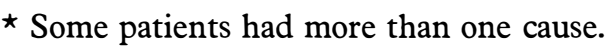




\section{SUMMARY}

During the period between 1972 to 198040 patients with end-stage renal disease (ESRD) associated with longstanding spinal cord injury were treated with maintenance hemodialysis in our unit. An additional i8 patients with acute or chronic renal failure also received temporary treatments in our facility who are not included in this report. Of the 40 reported cases 28 were paraplegic, I 2 quadriplegic; nine patients are alive and $3 \mathrm{I}$ are dead.

Survival on dialysis was significantly shorter $(5.5 \pm 5.0$ months $)$ in quadriplegics than paraplegics $(22.9 \pm 27.0$ months). The cumulative one-year survival was 60 per cent in paraplegics and 34 per cent in quadriplegics. The respective values for 2 -year survival were 52 per cent and 17 per cent. It thus appears that quadriplegic patients with end-stage renal disease have a considerably poorer prognosis than the paraplegics. In contrast to the ambulatory ESRD patients in whom arteriosclerotic cardiovascular disease is the primary cause of death various infectious complications constituted the immediate cause of death in the majority of our patients.

\section{RÉSUMÉ}

Nous avons treate 40 malades atteinte de medulaires avec insuffisance renale chronique au courd de 1972-1980 par hemodialyse chronique.

De 40 cas, 28 etudient paraplegiques et 12 quadriplegiques. Nous avons ansi treate I 9 malades d'atteintes medulo-spinales avec insuffisance renale aigues au coure de cette periode que no sons pas incoporet dans ce raport. De cette 40 malades, 31 sons decedee, mais 9 vivents. Suivie sur hemodialyse, des malades atteinte medulaire avec insuffisance renal chronique est extrememens court $(5.5 \pm 5.0$ mois) particulierement dans les quadriplegiques que les paraplegiques.

Suivie comultative est $60 \%$ chez les paraplegiques est $34 \%$ chez les quadriplegiques. Il est bien apparent de cette etude que la suivie chez quadriplegiques est estremement moins que les paraplegique. Les causes de martalities chez les malades d'atteintes I medullaire avec insuffisance renal, sons infections des diverse sources, du contraire, des malades d'atteintes insuffisance renales sans lesion medulaires, dans les quiles, les causes de mortalite sons complications cardio-vasculaires.

\section{ZUSAMMENFASSUNG}

Zwischen 1972 und 1980 haben wir vierzig Patienten mit letzter Etage Nierenkrankheiten verbunden mit lang stehender Ruckenmarkverletzung in unseren Abteilung mit Blutdialyse behandelnd. Achtzehn weitere Patienten mit akuter oder chronischer Nierversaumnis empfingen auch zeitweilige Behandlung in unseren Abteilung aber diese Patienten sind in diesem Bericht nicht eingeschlossen. Aus den 40 berichteten Krankheitsfallen hatten 28 Patienten beiderseitige Lahmung und 12 viergliedrige Lahmung. Neun Patienten leben noch und einunddreizig sind tot.

Das Uberleben auf Dialyse was bedeutsam kurzer ( $5.5 \pm 5.0$ Monaten) in viergliedrige Lahmung als in beiserseitigen Lahmung $(22 \cdot 9 \pm 27 \cdot 0)$ Monaten. Das kumulative Ijahrlige Uberleben war $60 \%$ in beiderseitigen Lahmung und 34\% in viergliedrigen Lahmung. Die respektiven Werte von 2-jahrlichem Uberleben waren $52 \%$ und $17 \%$. So scheint es dasz Patienten mit viergliedrige Lahmung und zuendegehender Nierkrankheit ein viel schlechtere Prognose haben als die mit beiderseitiger Lahmung. Im Gegensatz zu abmulanten auendegehende nierenkrankheit. Patienten in welchen arterienverkalikungende Herzkrankheit der Haupttodesgrund ist, waren verschiedene infektiose Verwickelungen die Haupttodsurasche in der Mehrheit von unseren Patienten.

\section{REFERENCES}

CUtLer, S. J. \& EDERER, F. (1958). Maximumutilization of the life table method in analyzing survival. F. Chronic. Dis., 8, 699-7I2. 
Lindner, A., Charra, B., Sherrard, D. J. et al. (I974). Accelerated atherogenesis in prolonged maintenance hemodialysis. N. Engl.f. Med., 290, 697-701.

Mirahmadi, M., Winer, R., Gorman, J. T., Sawnhey, A. Sankaram, R., Williams, T. \& KAPLAN, M. S. (I977). Hemodialysis in spinal cord injury patients with chronic renal failure. Dialysis $\mathcal{E}$ Transplantation, 6, 6-10.

Mitchell, G. (I964). The use of haemodialysis in renal failure complicating paraplegia. Paraplegia, 2, 254-26I.

Report of the Committee on Chronic Kidney Disease, C. G. Gottschalk, Chairman, U.S. Bureau of the Budget, Washington, D.C. U.S. Government Printing Office, September I 967.

Ross, J. C. (I95I). Management of the bladder in spinal cord injuries. Brit. Med.F. I, 6I6-6I9.

Siemsen, A. W. \& Lumeng, J. (1973). Study of reuse of cuprophane and cellophane coils. Proceedings of the Sixth Annual Contractors Conference of Artificial Kidney Progress NIAMDD, 95.

Tribe, C. R. \& Silver, J. R. (1969). Renal Failure in Paraplegia. London, Pitman Medical, pp. 13 and 89. 